
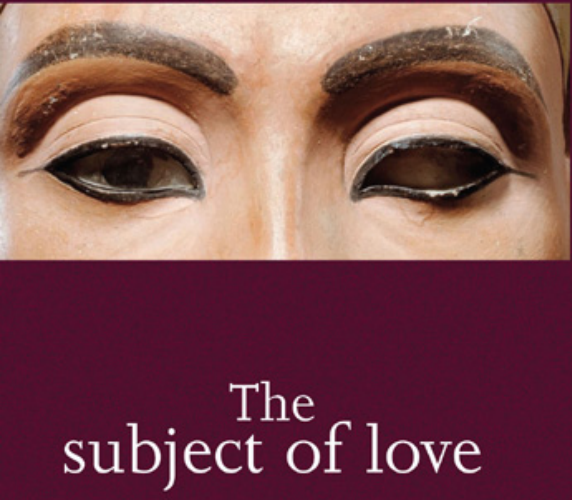

Hélène Cixous and the feminine divine

\title{
Sal Renshaw
}




\section{The subject of love}

\section{MANCHESTER 1824}

Manchester University Press 
This series was edited by the late Grace M. Jantzen

Already published

\section{Religion and culture}

Michel Foucault

selected and edited by Jeremy R. Carrette

\section{Representations of the post/human}

Monsters, aliens and others in popular culture

Elaine L. Graham

\section{Becoming divine}

Towards a feminist philosophy of religion

Grace M. Jantzen

\section{Divine love}

Luce Irigaray, women, gender, and religion

Morny Joy

\section{Literature, theology and feminism}

Heather Walton 


\title{
The subject of love
}

Hélène Cixous and the feminine divine

\author{
Sal Renshaw
}

Manchester University Press

Manchester and New York

distributed in the United States exclusively by

by Palgrave Macmillan 
The right of Sal Renshaw to be identified as the author of this work has been asserted by her in accordance with the Copyright, Designs and Patents Act 1988.

Published by Manchester University Press Oxford Road, Manchester M13 9NR, UK

and Room 400, 175 Fifth Avenue, New York, NY 10010, USA

www.manchesteruniversitypress.co.uk

Distributed in the United States exclusively by

Palgrave Macmillan, 175 Fifth Avenue, New York,

NY 10010, USA

Distributed in Canada exclusively by

UBC Press, University of British Columbia, 2029 West Mall,

Vancouver, BC, Canada V6T 1 Z2

British Library Cataloguing-in-Publication Data

A catalogue record for this book is available from the British Library

Library of Congress Cataloging-in-Publication Data applied for

ISBN 9780719069604 hardback

First published 2009

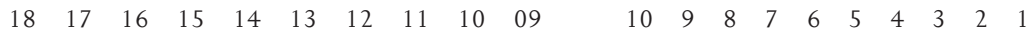

Typeset

by Graphicraft Limited, Hong Kong

Printed in Great Britain

by the MPG Books Group 